\title{
Rewitalizacja i jej znaczenie w kontekście realizacji polityki przestrzennej na terenie województwa mazowieckiego
}

\section{Alina Maciejewska, Agnieszka Turek}

\section{STRESZCZENIE}

Nieustanne rozrastanie się miast wymaga przyjęcia kompleksowych rozwiązań w zakresie sposobu organizacji ich struktury. Rewitalizacja zdegradowanych obszarów poprzemysłowych, a w konsekwencji skierowanie rozwoju miast do wewnątrz, może mieć kluczowe znaczenie w kontekście realizacji zasady zrównoważonego rozwoju w procesie planowania przestrzennego.

Celem artykułu jest wskazanie potrzeby i znaczenia procesu rewitalizacji dla rozwoju lokalnego i regionalnego. Opisano historię procesu rewitalizacji w Polsce, omówiono specyfikę i skalę degradacji obszarów poprzemysłowych, ze szczególnym uwzględnieniem województwa mazowieckiego, a także wskazano przykłady dobrych praktyk zagranicznych w zakresie rewitalizacji obszarów poprzemysłowych.

Słowa kluczowe: rewitalizacja, obszary poprzemysłowe, obszary zdegradowane, województwo mazowieckie

\section{Wstęp}

Współczesne procesy urbanizacyjne wymuszają racjonalne gospodarowanie przestrzenia, zgodnie ze strategią zrównoważonego rozwoju, poprawiające parametry gospodarcze, społeczne i ekologiczne. W tym kontekście kluczowym zagadnieniem staje się ponowne wykorzystanie opuszczonych, poprzemysłowych, powojskowych, pokolejowych terenów, w szczególności zdegradowanych. Tereny takie charakteryzują się najczęściej atrakcyjną lokalizacją oraz istniejąca, lecz w różnym stanie, infrastrukturą. Stopień degradacji często uniemożliwia ich ponowne zagospodarowanie, co w konsekwencji wpływa negatywnie na aspekty społeczne, gospodarcze i przyrodnicze. Stanowi to kluczowy element przy opracowywaniu strategii rozwoju miast i regionów.

Celem artkułu jest wskazanie potrzeby rewitalizacji obszarów zdegradowanych, zgodnie z obowiązującą ustawą o rewitalizacji, jako ważnego elementu polityki rozwoju lokalnego i regionalnego.

\section{Proces rewitalizacji w Polsce w ujęciu historycznym}

Przemiany społeczno-gospodarcze w Polsce i przyrost terenów poprzemysłowych po 1989 r. wskazywały na potrzebę przekształceń, odnowy i ponownego zagospodarowania obszarów zdegradowanych [Domański 2009]. Brak odpowiednich regulacji prawnych i instrumentów finansowych w tym zakresie, w poważnym stopniu ograniczał proces 
przekształceń. Pomimo to gminy podejmowały działania naprawcze stosując instrumenty lokalne, jak na przykład program małych ulepszeń realizowany w Szczecinie [MuziołWęcławowicz 2009].

Pierwsze działania rewitalizacyjne w Polsce podejmowane były na początku lat 90 . XX w. Wykorzystywano wówczas fundusze unijne, $\mathrm{w}$ tym przedakcesyjne, przyznawane na podstawie opracowywanych programów gminnych [Muzioł-Węcławowicz 2009].

Drugi okres programowania procesu rewitalizacji przypadał na lata 2004-2006 i wiązał się z przede wszystkim z dostępem do środków unijnych. Gminy opracowywały Lokalne Programy Rewitalizacji (LPR), które ze względu na brak odrębnych regulacji prawnych dotyczących rewitalizacji, przyjmowane były na podstawie ustawy o samorządnie gminnym. Lokalne Programy Rewitalizacji (LPR), opracowane zgodnie z wytycznymi przyjętymi przez instytucje wdrażające, stanowiły niezbędny dokument przy ubieganiu się o środki finansowe z Europejskiego Funduszu Rozwoju Regionalnego (EFRR) na realizację projektów odnowy obszarów zdegradowanych w ramach Zintegrowanego Programu Operacyjnego Rozwoju Regionalnego (ZPORR, Działanie 3.3. Zdegradowane obszary miejskie, poprzemysłowe i powojskowe). Zintegrowany Program Operacyjny Rozwoju Regionalnego (ZPORR) miał charakter dokumentu regulacyjnego i stanowił wzór struktury Lokalnych Programów Rewitalizacji, przyczyniając się tym samym do popularyzacji programów rewitalizacji w kraju.

Trzeci okres programowania procesu rewitalizacji w Polsce przypadał na lata 20072013, kiedy w ramach Regionalnych Programów Operacyjnych (RPO) finansowano projekty zgłaszane w Lokalnych Programach Rewitalizacji.

Kolejny proces rewitalizacji rozpoczął się w 2014 r. i będzie kontynuowany do $2020 \mathrm{r}$. $\mathrm{w}$ ramach priorytetu inwestycyjnego $9 \mathrm{~b}$ - „Wspieranie rewitalizacji fizycznej, gospodarczej i społecznej ubogich społeczności na obszarach miejskich $i$ wiejskich" i jest skierowany wyłącznie na realizację projektów rewitalizacyjnych [Minister Rozwoju 2016, s. 10].

Należy podkreślić, że środki na rewitalizacje pozyskiwano także w ramach krajowych programów operacyjnych, były to, m.in.: Program Rozwój Polski Wschodniej (finansowany z EFRR), Program Kapitał Ludzki (współfinansowany z Europejskiego Funduszu Społecznego EFS), Program Infrastruktura i Środowisko (współfinansowany z EFRR i Funduszu Spójności), Program Innowacyjna Gospodarka (EFRR), Programy Europejskiej Współpracy Terytorialnej (EFRR), Program Pomoc Techniczna (EFRR).

Analiza projektów rewitalizacyjnych, współfinansowanych ze środków unijnych w okresie programowania 2004-2006 oraz 2007-2013 wskazuje, że podejmowane inwestycje często nie realizowały zamierzonych celów. W dużej mierze ograniczały się do remontów i działań punktowych, bez uwzględnienia lokalnego biznesu czy też działań „miękkich”, skierowanych do społeczności lokalnych. Samorządy podejmowały często działania wybiórcze, bez spójnej, kompleksowej wizji wyprowadzania danego obszaru ze stanu kryzysowego. Ograniczano się najczęściej do jednego źródła finansowania, bez 
wykorzystania form partnerstwa publiczno-prywatnego ${ }^{1}$ [Kołacz, Wielgus 2015]. Krytycznie oceniane są zwłaszcza Lokalne Programy Rewitalizacji, opracowane w pierwszym okresie programowania. Zamiast kompleksowej rewitalizacji, powstały $\mathrm{w}$ gminach dokumenty nieprzydatne do zamierzonego przez Unię Europejską celu. Procedura sporządzania i zakres wymaganych dokumentów sprawił, że gminy starające się o dofinansowanie działań rozwojowych, zlecały opracowanie dokumentu osobom z zewnątrz. Ze względu na krótki termin przeznaczony na opracowanie dokumentacji, ich wykonawcy sporządzali charakterystykę aktualnej sytuacji w gminie na podstawie istniejącej Strategii Rozwoju Gminy, nieznacznie ją aktualizując i wypełniając tym materiałem ponad 50\% objętości dokumentu [Chmielewski 2007].

Należy jednak podkreślić, że po 2000 r. na terenach poprzemysłowych powstawały również komercyjne projekty przekształceń typu rewitalizacyjnego. Realizacje takie stanowiły prywatne projekty biznesowe, podejmowane zgodnie z zasadami rewitalizacji, choć poza formalnymi programami gminnymi. Przedsięwzięcia te stanowią rozpoznawalne projekty dużej skali. Przykładem jest przekształcenie i adaptacja na potrzeby centrum handlowego Manufaktura dawnego kompleksu fabrycznego Izraela Poznańskiego w Łodzi, oddanego do użytku w 2006 r., czy też Centrum Sztuki i Handlu Stary Browar w Poznaniu, otwarte w 2003 r. [Turek 2017].

Aktualny etap procesu rewitalizacji to realizacja ustawy o rewitalizacji, która weszła w życie 9 października 2015 r., niemal po 20 latach, od kiedy polskie gminy realizują programy wyprowadzania zdegradowanych obszarów ze stanu kryzysowego. Ustawa określa cele, zasady oraz tryb przygotowania, prowadzenia i oceny rewitalizacji, a także udostępnia samorządom szereg narzędzi ułatwiających realizację tego procesu. Ustawa definiuje rewitalizację jako „proces wyprowadzania ze stanu kryzysowego obszarów zdegradowanych, prowadzony w sposób kompleksowy, poprzez zintegrowane działania na rzecz lokalnej społeczności, przestrzeni i gospodarki, skoncentrowane terytorialnie, prowadzone przez interesariuszy rewitalizacji na podstawie gminnego programu rewitalizacji" [Ustawa o rewitalizacji 2015, art. 2.1]. Jest to zespół działań wieloaspektowych, obejmujących zabiegi środowiskowe, przestrzenne, społeczne, gospodarcze i techniczne. $Z$ zapisów ustawowych wynika, że rewitalizacja stanowi ważny element polityki rozwoju, jest fakultatywnym zadaniem własnym gminy i nie jest jedynie formą interwencji kryzysowej.

Ustawa reguluje także kwestie dotyczące Gminnych Programów Rewitalizacji (GPR), których opracowanie, zgodnie z procedurą zapisaną w art. 14-24 ustawy o rewitalizacji, jest warunkiem niezbędnym do skorzystania z udogodnień zaproponowanych $\mathrm{w}$ ustawie. Gminne Programy Rewitalizacji są podstawowym narzędziem prowadzenia rewitalizacji, zapewniającym jego kompleksowość i aktywny udział interesariuszy, jak partycypacja społeczna czy konsultacje społeczne. Ustawa wprowadza również dwa fakultatywne rozwiązania usprawniające prowadzenie procesu rewitalizacji w gminie, to jest możliwość

\footnotetext{
${ }^{1}$ Partnerstwo publiczno-prywatne w Polsce reguluje ustawa z dnia 19 grudnia 2008 r. o partnerstwie publiczno-prywatnym (Dz.U. z 2015 r., poz. 696 z późn. zm.).
} 
utworzenia na rewitalizowanym terenie Specjalnej Strefy Rewitalizacji (SSR) oraz możliwość uchwalenia miejscowego planu rewitalizacji, będącego szczególną formą miejscowego planu zagospodarowania przestrzennego [Ustawa o planowaniu $i$ zagospodarowaniu przestrzennym 2003, art. 37f]. Stanowi on podstawę realizacji przekształceń urbanistycznych oraz prac inwestycyjno-budowlanych ujętych w GPR. Ustawa określa również obowiązki gmin związane z zapewnieniem partycypacji [Ministerstwo Infrastruktury i Budownictwa 2016; Ustawa o rewitalizacji 2015; Ministerstwo Rozwoju 2015]. Ustawa ta nie zapewnia jednak żadnych dodatkowych działań ukierunkowanych na specyfikę obszarów poprzemysłowych. Zgodnie z ustawa, niezamieszkane tereny poprzemysłowe mogą wejść do obszaru rewitalizacji tylko $\mathrm{w}$ przypadku, gdy działania możliwe do przeprowadzenia na tych terenach przyczynią się do przeciwdziałania negatywnym zjawiskom społecznym (art. 10 ust. 3 ustawy) [Turek 2017].

\section{Specyfika obszarów poprzemysłowych}

Obszary poprzemysłowe stanowią szczególny rodzaj obszarów wymagających rewitalizacji. W Polsce pojęcie terenów poprzemysłowych nie zostało ustawowo uregulowane, a metody postępowania $\mathrm{z}$ takimi obszarami nie są jasno określone. Tereny poprzemysłowe cechuje utrata dotychczas pełnionej funkcji i wyłączenie obszaru z użytkowania. B. Domański [2009] wyróżnia dwa typy terenów poprzemysłowych, w zależności od ich genezy i cech fizycznych. Pierwszy rodzaj to tereny pofabryczne, które przestały być miejscem produkcji lub zaprzestały pełnienia funkcji pomocniczych w obrębie zakładów przemysłowych (np. magazynowo-składowe, transportowe) wraz $\mathrm{z}$ obszarami niedokończonych inwestycji przemysłowych. Do drugiego typu terenów poprzemysłowych zalicza obszary zdegradowane przez działalność przemysłową w tym górniczą lub składowanie odpadów.

Z kolei K. Gasidło [1998] do obszarów poprzemysłowych zalicza nie tylko nieruchomości, w których odbywała się produkcja przemysłowa, ale również obszary po urządzeniach gospodarki komunalnej, osiedla pracownicze czy infrastrukturę w ich pobliżu. W szerszym ujęciu są to obszary oddziaływania przemysłu - fizycznego, ekonomicznego oraz społecznego.

Program rządowy dla terenów poprzemysłowych przyjęty przez Radę Ministrów w dniu 27 kwietnia $2004 \mathrm{r}$. definiuje tereny poprzemysłowe jako „zdegradowane, nieużytkowane lub nie w petni wykorzystane tereny przeznaczone pierwotnie pod działalność gospodarcza, która została zakończona" [Ministerstwo Środowiska 2004, s. 3]. W dokumencie tym pojawia się definicja pojęcia rekultywacja (łac. re+cultivo - „uprawiać na nowo”), które obejmuje działania mające na celu przywrócenie naturalnego ukształtowania terenu i/lub osiągnięcie przez glebę lub ziemię zawartości substancji zgodnych z wymaganymi normami, pozwalające na nadanie lub przywrócenie terenom zdegradowanym wartości użytkowych lub przyrodniczych. W najprostszym ujęciu termin rekultywacja oznacza przywrócenie użyteczności terenom zniszczonym wskutek działalności gospodarczej [Cymerman 1988; Maciejewska 2000]. 
Rekultywacja, będąca integralną częścią ochrony środowiska, jest procesem złożonym, dlatego stworzenie jednolitego systemu prawnego regulującego tę dziedzinę działalności człowieka jest trudne. Ustawa z dnia 3 lutego 1995 r. o ochronie gruntów rolnych i leśnych definiuje rekultywację jako "nadanie lub przywrócenie gruntom zdegradowanym albo zdewastowanym wartości użytkowych lub przyrodniczych przez wtaściwe ukształtowanie rzeźby terenu, poprawienie właściwości fizycznych i chemicznych, uregulowanie stosunków wodnych, odtworzenie gleb, umocnienie skarp oraz odbudowanie lub zbudowanie niezbędnych dróg" [Ustawa o ochronie gruntów rolnych i leśnych 1995, art. 4 pkt 18].

Powstawanie obszarów poprzemysłowych jest nieuchronnym zjawiskiem przestrzennym, wynikającym z określonego procesu użytkowania terenu, wpływu działalności gospodarczej na środowisko naturalne, antropogeniczne i społeczne oraz nierównomierności w rozwoju gospodarczym i zmiany w nim zachodzące. Szczególnie intensywna przemiana struktury gospodarczej w Europie Centralnej i Wschodniej rozpoczęła się po 1989 r. Nastąpiły zmiany własnościowe, organizacyjne i technologiczne istniejącego przemysłu. Restrukturyzacja zakładów produkcyjnych, hut i stalowni, odejście od monokultur przemysłu ciężkiego, likwidacja kopalń oraz zmiany technologiczne w pozostałych gałęziach przemysłu spowodowały pojawienie się terenów poprzemysłowych wraz z towarzyszącymi im negatywnymi zjawiskami środowiskowymi, przestrzennymi i ekonomiczno-społecznymi, takimi jak: bezrobocie, migracja, szkody ekologiczne, degradacja krajobrazu, opuszczanie przez zakłady dzielnic przemysłowych [Gasidło 1998]. Do podstawowych przyczyn transformacji dzielnic przemysłowych należy zaliczyć: konieczność ochrony środowiska, wdrażanie nowych technologii (głównie mechanizacja produkcji), nowe techniki transportu produkcji oraz jej organizacyjne rozdrobnienie [Kopeć 2010].

W Polsce zaczęto bardziej racjonalnie zarządzać przestrzenią $\mathrm{w}$ okresie przemian ustrojowych, które nastąpiły po roku 1989. Zwrócono uwagę na nadmiar terenów zajmowanych przez przedsiębiorstwa przemysłowe. Zmianie uległy zasady i mechanizmy rozwoju miast, a także ich znaczenie funkcjonalne $\mathrm{w}$ przestrzeni, związane m.in. z wprowadzeniem rynkowych zasad gospodarowania i zmianą systemu własności. Współpraca zagraniczna wymusiła ograniczenie kosztów produkcji i, przede wszystkim, podniesienie jej jakości oraz wprowadzenie nowoczesnych i zaawansowanych technologii. Wymogi unijne stanowiły impuls do wprowadzenia zmian ekonomicznych i prawnych w zakresie ochrony środowiska. Przemysł radykalnie ograniczył niekorzystne oddziaływanie na środowisko przyrodnicze. Także aktywizacja mieszkańców i organizacji ekologicznych wymusiła restrukturyzację produkcji [Kopeć 2010]. Niektóre przedsiębiorstwa nie zdołały przystosować się do nowych realiów gospodarki konkurencyjnej, co doprowadziło do ich upadku. Przyczyną degradacji wielu przedsiębiorstw był również brak jakichkolwiek nakładów inwestycyjnych.

Przemysł przez wiele dziesięcioleci oddziaływał wyjątkowo negatywnie na środowisko - zarówno naturalne jak i antropogeniczne. Rewitalizacja terenów poprzemysłowych wiąże się z problemem zanieczyszczeń i skażeń. Podstawowym celem przekształcenia 
zdewastowanych obszarów poprzemysłowych, w odniesieniu wyłącznie do środowiska naturalnego, jest po pierwsze likwidacja szkodliwego oddziaływania pozostających na miejscu zanieczyszczeń, a po drugie wytworzenie odpowiedniego, zrównoważonego ekosystemu, czyli aktywacja biologiczna obszaru [Maciejewska 2000]. Dopiero po wykonaniu takich zabiegów możliwe jest ponowne wykorzystanie obszaru poprzemysłowego.

\section{Zagraniczne przykłady rewitalizacji obszarów poprzemysłowych}

Szczegółowa diagnoza i analiza podejmowanych działań rewitalizacyjnych stanowią podstawę badań metodycznych nad systemami wspomagającymi i usprawniającymi planowane inwestycje w tym zakresie. Analiza doświadczeń zagranicznych, z krajów o dłuższej historii działań rewitalizacyjnych niż projekty polskie, umożliwia wskazanie zagadnień, na które szczególnie należy zwrócić uwagę podczas organizacji procesu rewitalizacji oraz pozwala skorzystać z metodologii poprawnie zrealizowanych projektów. Z drugiej strony może stanowić ostrzeżenie przed potencjalnymi zagrożeniami i problemami, jakie mogą wystąpić w procesie odnowy i przekształceń [Turek 2017].

W Europie Zachodniej przestrzenno-funkcjonalne przekształcenia terenów poprzemysłowych realizowano od lat 70. XX w. Z kolei w krajach Europy Środkowej, pierwsze realizacje tego typu podejmowano dopiero w latach 90. XX w. Zagadnienie opuszczonych obszarów poprzemysłowych dotyczy nie tylko wielkich okręgów i miast przemysłowych (jak Zagłębie Ruhry, Manchester), ale także wielu miast niekojarzonych bezpośrednio z przemysłem, jak również małych i średnich ośrodków miejskich [Gasidło 2010].

Proces rewitalizacji realizowany w Niemczech, skierowany jest na uruchomienie kapitałów umożliwiających modernizację i rozwój społeczno-gospodarczy, które są kompatybilne z celami unijnego rozwoju miasta [Billert 2010]. Metropolia Ruhry (dawniej Zagłębie Ruhry) jest jednym z największych obszarów postindustrialnych w Europie. Jej przemysłowa przeszłość związana była z intensywnym rozwojem górnictwa węgla kamiennego oraz hutnictwa żelaza i stali. Obecnie region ten ma za sobą ponad 50 lat restrukturyzacji przemysłu oraz rewitalizacji przestrzeni poprzemysłowej, które doprowadziły do poprawy jakości środowiska i zmiany wizerunku regionu [Chmielewska 2012; Maciejewska, Turek 2014].

Kluczowym przedsięwzięciem dotyczącym tego obszaru była Międzynarodowa Wystawa Budownictwa (IBA) Emscher Park. Program, realizowany w latach 1989-1999 z inicjatywy rządu Północnej Nadrenii-Westfalii, miał na celu rewitalizację zdewastowanego pod wpływem przemysłu krajobrazu o powierzchni około $800 \mathrm{~km}^{2}$, gdzie mieszka około 2,5 mln ludzi. Obszar zlokalizowany jest wzdłuż Emscher, małej rzeki na północy Zagłębia Ruhry, zdegradowanej do roli ścieku przemysłowego [Urbańczyk 2009; Chmielewska 2012; Maciejewska, Turek 2014].

Głównym założeniem rewitalizacji tego obszaru było stworzenie wspólnej strategii rewitalizacyjnej dla 17 miast i gmin wzdłuż rzeki Emscher, ze szczególnym uwzględnieniem terenów poprzemysłowych. Ich efektem miało być wzmocnienie identyfikacji mieszkańców ze swoim regionem oraz zainteresowanie nim inwestorów. W konsekwencji, w ramach IBA 
Emscher Park, powstało ponad 400 projektów, spośród których zrealizowano około 120 [Maciejewska, Turek 2014]. Planowanie w ramach projektu przebiegało na trzech płaszczyznach: koncepcja i strategia dla całego projektu, plany ramowe dotyczące obszarów częściowych oraz metoda "małych kroków" - plany projektowe gmin i podmiotów prywatnych [Hunger, Weidemüller, Westermann 2005].

Wizja planowania na podstawie zasady wzajemnego oddziaływania pomiędzy koncepcją ogólną a konkretnymi projektami zainicjowanymi oddolnie, zakłada otwartość procesu planowania. Metoda ta polegała na działaniu zmierzającym do realizacji długofalowych celów politycznych dotyczących odnowy regionu, przy wykorzystaniu regionalnego potencjału i w kooperacji z partnerami regionalnymi i ponadregionalnymi, instytucjami i lokalną społecznością [Hunger, Weidemüller, Westermann 2005].

Jednym z wielu projektów rewitalizacyjnych realizowanych na terenach poprzemysłowych w Zagłębiu Ruhry jest projekt Phoenix Dortmund. Projekt obejmuje kompleksową rewitalizację zdegradowanej przez przemysł części dzielnicy Hörde w Dortmundzie, o powierzchni około 200 ha, połączoną z renaturalizacją rzeki Emscher.

Realizacja projektu rozpoczęła się po zamknięciu ostatniego wielkiego pieca w $1998 \mathrm{r}$. Całość jest współfinansowana ze środków Unii Europejskiej oraz funduszy Landu Północ-

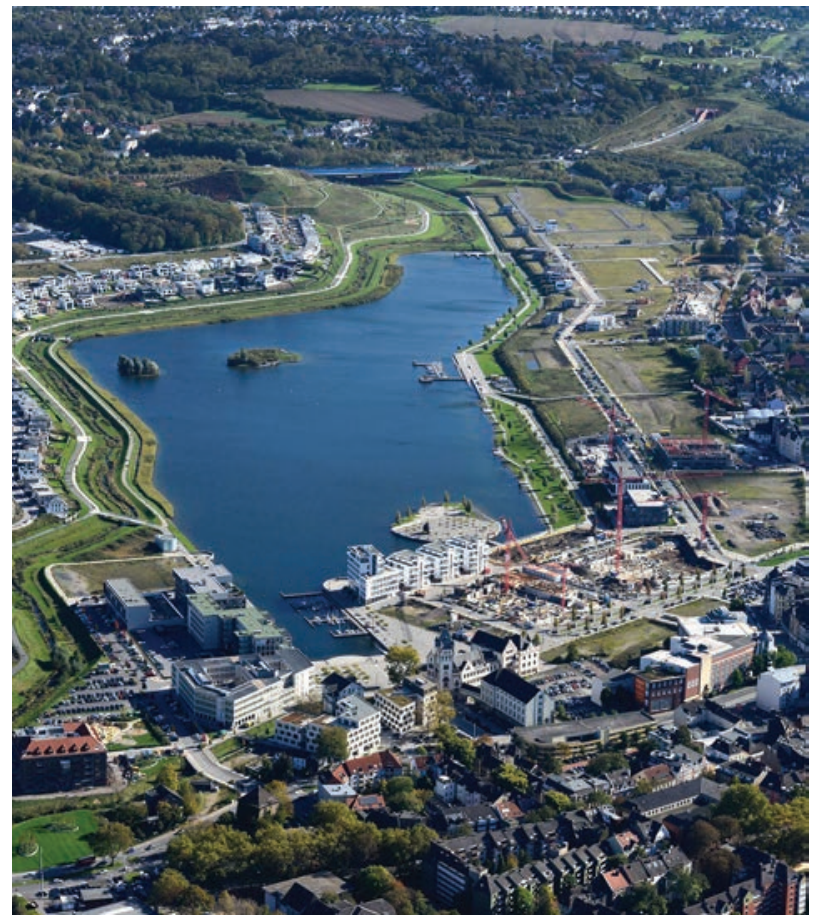

Ryc.1. Projekt Phoenix See Źródło:

https://www.thinglink.com/scene/578921371585740802 na Nadrenia-Westfalia. Obszar podzielony został na dwie zróżnicowane funkcjonalnie części: Phoenix Ost (część wschodnia) i Phoenix West (część zachodnia), oddzielone od siebie poprzez historyczne centrum Hörde, połączone natomiast przez rzekę Emscher opływającą je od północy.

Część zachodnią stanowią park technologiczny i tereny rekreacyjne, gdzie utworzono centrum technologiczno-usługowe. Realizację projektu rozpoczęto od przygotowania infrastruktury technicznej i drogowej, do pełnienia nowych funkcji zaadaptowano też kilka zachowanych obiektów pohutniczych.

Część wschodnia to dzielnica mieszkaniowa, gdzie w miejscu dawnej huty Phoenix realizowany jest projekt Phoenix 
See (Jezioro Phoenix). Plan przyszłego zagospodarowania tego terenu zakłada utworzenie atrakcyjnej przestrzeni mieszkaniowej i rekreacyjnej, ze sztucznym zbiornikiem wodnym w centrum. Projekt skutkował przeobrażeniami na dużą skalę - zmienił się zarówno krajobraz i morfologia dzielnicy, jak i funkcje spełniane przez poszczególne elementy jej przestrzeni [Chmielewska 2012] (ryc. 1).

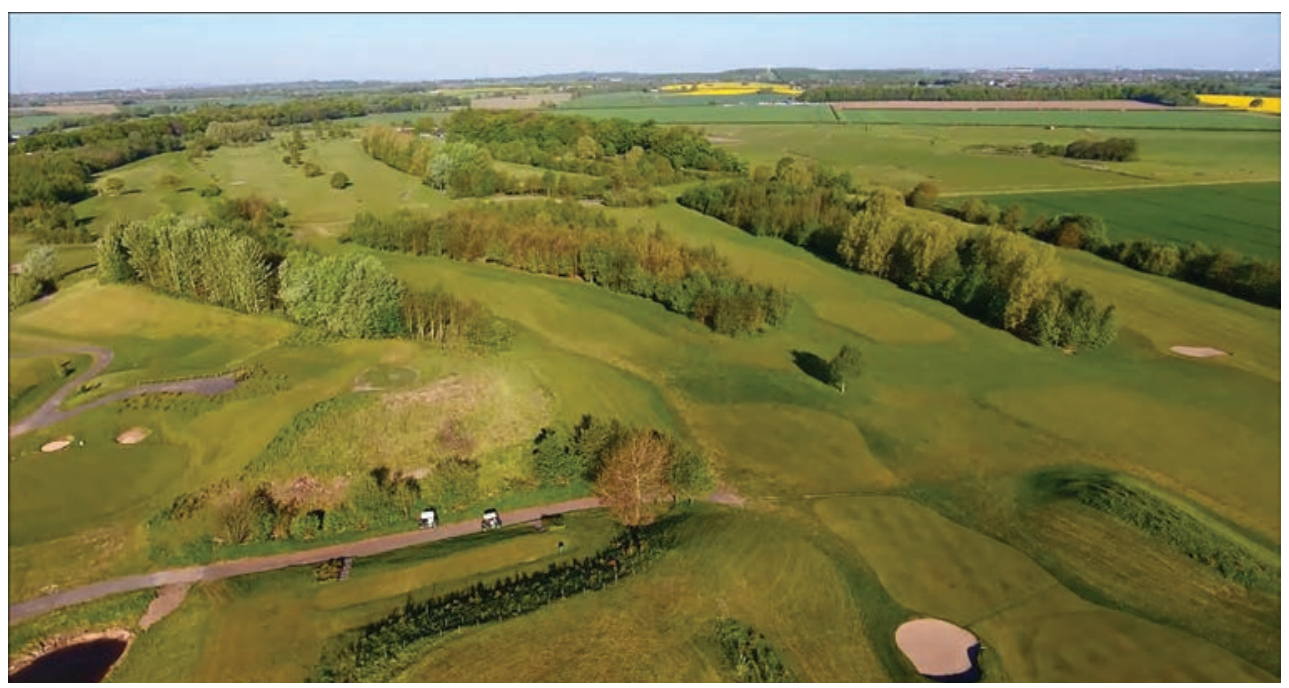

Ryc. 2. Projekt Mersey Valley

Źródło: Mersey Valley Golf \& Country Club

Kolejnym wiodącym państwem $\mathrm{w}$ zakresie prowadzenia procesu rewitalizacji jest Wielka Brytania. Projekt Mersey Valley zajmuje obszar zbliżony do dawnej równiny zalewowej przed objęciem terenu ochroną przeciwpowodziową. Już w 1967 r. lokalne władze podjęły działania mające na celu poprawę stanu Mersey Valley, głównie w kierunku rekreacyjnym [Turek 2017] (ryc. 2).

Do głównych celów projektu należy zaliczyć poprawę stanu środowiska, krajobrazu, ochronę przyrody, przywrócenie i ochronę obszarów wiejskich. Wprowadzono funkcje rekreacyjne i zachęcono wszystkie grupy społeczne do spędzania czasu w dolinie. Władze poprawiły również komunikację wewnątrz i dostęp do doliny, wykorzystując istniejące trasy oraz łącząc je z nowymi, rekreacyjnymi szlakami komunikacyjnymi [Trafford Metropolitan Borough 1993].

W ramach projektu opracowano plan terenów zieleni, które zostały podzielone na obszary o zróżnicowanym sposobie zagospodarowania. W odróżnieniu od polskich opracowań planistycznych, określa on dokładnie przeznaczenie terenów pod różne formy zagospodarowania zielenią. Znajdują się tu zarówno pola golfowe, stawy dla rybaków, jak i tereny pokryte gęstą roślinnością łąki, bagna oraz tereny mające charakter zieleni łęgowej, ważnej dla utrzymania wilgotności i poprawy wentylacji [Mersey Valley CountrysideWarden Service 2014]. 
Istotną cechą projektu jest fakt, iż władze nie dopuściły do zabudowy deweloperskiej, chcąc stworzyć reprezentacyjne tereny rekreacyjne dla mieszkańców. Na uwagę zasługuje również model organizacji przedsięwzięcia [Tödtling-Schönhofer, Davies 2013].

Doświadczenia zagraniczne wskazuja, że efektywna rewitalizacja obszarów poprzemysłowych wymaga działań kompleksowych. Wielofunkcyjne zagospodarowanie - jednoczesne wzmacnianie funkcji mieszkaniowych, gospodarczych, rekreacyjnych i kulturalnych sprzyja poprawie jakości życia.

\section{Skala problemu obszarów poprzemysłowych w Polsce}

Trudno jest jednoznacznie określić dokładną powierzchnię zdegradowanych gruntów poprzemysłowych $\mathrm{w}$ Polsce. Wynika to przede wszystkim $\mathrm{z}$ braku szczegółowych informacji na temat występujących zanieczyszczeń oraz braku systemu identyfikacji terenów poprzemysłowych. Analizując skalę problemu, należy także mieć na uwadze nierównomierne obciążenie powierzchni kraju zanieczyszczeniami historycznymi. Szacunkowa skala degradacji przemysłowej przedstawiona została na rycinie 3. Indeks przemysłowej degradacji według powiatów określa procentową powierzchnię wszystkich form degradacji w jednostce administracyjnej. Inne badania nad skalą degradacji przemysłowej przeprowadzono w $1999 \mathrm{r}$. Wynikało z nich, iż niewykorzystane tereny poprzemysłowe istniały wówczas w ponad 75\% miast liczących powyżej 50 tysięcy mieszkańców [Gasidło 2010]. Zgodnie z analizami przeprowadzonymi przez Ministerstwo Środowiska w 2002 r., w Polsce było wówczas około 3230 obiektów poprzemysłowych zajmujących łącznie około 800000 ha [Skalny, Białecka 2016]. Badania przeprowadzone w 2007 r. przez Instytut Rozwoju Miast wykazały, że około 21 \% obszarów miejskich jest zdegradowanych i wymaga rewitalizacji. Szacunkowo obszary te zamieszkuje około 2,4 mln osób. Potrzeby miast w zakresie rewitalizacji są zatem znaczące. Zgodnie z danymi Ministerstwa Rozwoju, w nowym okresie programowania 2014-2020 na rewitalizację przewidziano 25 mld złotych, przy czym w perspektywie finansowej 20072013 było to 5 mld złotych [Uzasadnienie rządowego projektu ustawy o rewitalizacji 2015; Jarczewski 2010].

Aktualne dane statystyczne znajdujące się w zasobach Głównego Urzędu Statystycznego w Polsce odnoszą się do kategorii gruntów zdewastowanych i zdegradowanych wymagających rekultywacji i w 2016 r. ich powierzchnia wyniosła łącznie 65 tys. ha [Główny Urząd Statystyczny 2017]. Pomimo obowiązku rekultywacji gruntu przez sprawcę jego degradacji lub dewastacji, tempo prac rekultywacyjnych jest obecnie niewystarczające, a powierzchnia gruntów wymagających rekultywacji pozostaje znaczna [Cymerman, Marcinkowska 2010]. W 2016 r. stopień rekultywacji wynosił 2,2\% a zagospodarowania 0,9\% ogólnej powierzchni gruntów zdewastowanych i zdegradowanych. Zgodnie z danymi Głównego Urzędu Statystycznego, w 2016 r. zrekultywowano 1,4 tys. ha gruntów, natomiast zagospodarowano około 0,6 tys. ha gruntów. Najwięcej gruntów wymagających rekultywacji i zagospodarowania znajduje się w województwach śląskim, wielkopolskim i dolnośląskim 


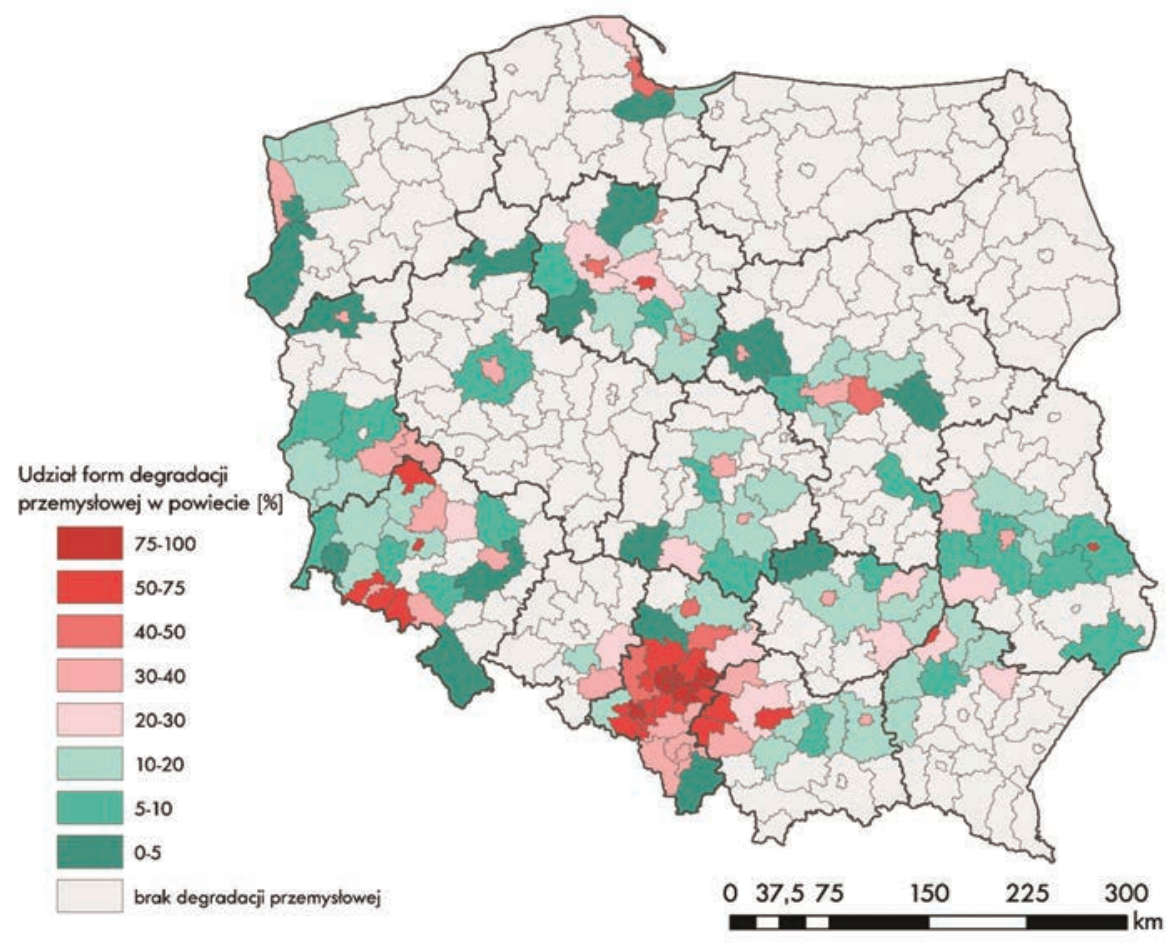

Ryc. 3. Indeks przemysłowej degradacji według powiatów (IDI)

Źródło: J. Siuta, A. Kucharska, R. Sienkiewicz 1996

[Główny Urząd Statystyczny 2017]. Podstawowymi kierunkami rekultywacji w Polsce są kierunki rolnicze i leśne [Cymerman, Marcinkowska 2010].

Dostępne dane odnoszące się do powierzchni terenów zdegradowanych i poprzemysłowych w Polsce charakteryzują się brakiem szczegółowości, odmienną rozpiętościa, a także brakiem korelacji pod względem czasowym i merytorycznym. Wskazuje to na potrzebę zapewnienia zintegrowanych i transparentnych informacji o tych terenach. Stworzenie rozwiązań systemowo wspierających zagospodarowanie tych obszarów może przyczynić się do zmniejszenia omawianej luki informacyjnej.

Państwa odnoszące największe sukcesy w rewitalizacji obszarów zdegradowanych, takie jak Niemcy, Francja i Wielka Brytania, opracowały krajowe bazy danych terenów poprzemysłowych i poprzednio zainwestowanych. W Wielkiej Brytanii jest to National Land Use Database of Previously Developed Land NLUD-PDL, we Francji i Niemczech działają obserwatoria lokalne i regionalne [Domański 2009]. Jak wcześniej wspomniano, do tej pory nie opracowano jednolitego systemu identyfikacji zdegradowanych terenów poprzemysłowych dla Polski. Wyjątkiem jest województwo śląskie, charakteryzujące się największą w skali kraju ilością terenów zdegradowanych, w tym poprzemysłowych, obejmującą około 12,5 tys. ha. Dla obszaru tego województwa stworzono Ogólnodostępną Platformę Informacji - 
Tereny Poprzemysłowe (OPI-TPP) (ryc. 4) [IETU/GIG 2008]. Jest to regionalna baza danych, która zawiera kompleksową informację o terenach poprzemysłowych oraz prowadzonej na nich działalności w odniesieniu do elementów środowiska przyrodniczego. Platforma ta stanowi integralną część Regionalnego Systemu Informacji Przestrzennej (RSIP) [Bondaruk, Zawartka 2011]. Platforma zawiera szczegółowe informacje dotyczące terenów znajdujących się w bazie. Po wybraniu konkretnego terenu można uzyskać metadane, tj. informacje dotyczące typu i nazwy obiektu, jego krótkiej charakterystyki, powierzchni, instytucji władającej terenem, statusu prawnego terenu (uregulowany lub nie), oceny czy obszar wymaga interwencji, informacji dotyczących stanu technicznego zabudowy, tego, czy obszar jest zanieczyszczony, czy znajduje się w obszarze chronionym bądź w granicach obszaru Natura 2000 i inne.

Znacznie mniej kompleksowe próby identyfikacji terenów poprzemysłowych i zdegradowanych podjęły jeszcze trzy inne województwa. W województwie mazowieckiem, w ramach pilotażowego projektu, Wojewódzki Inspektorat Ochrony Środowiska

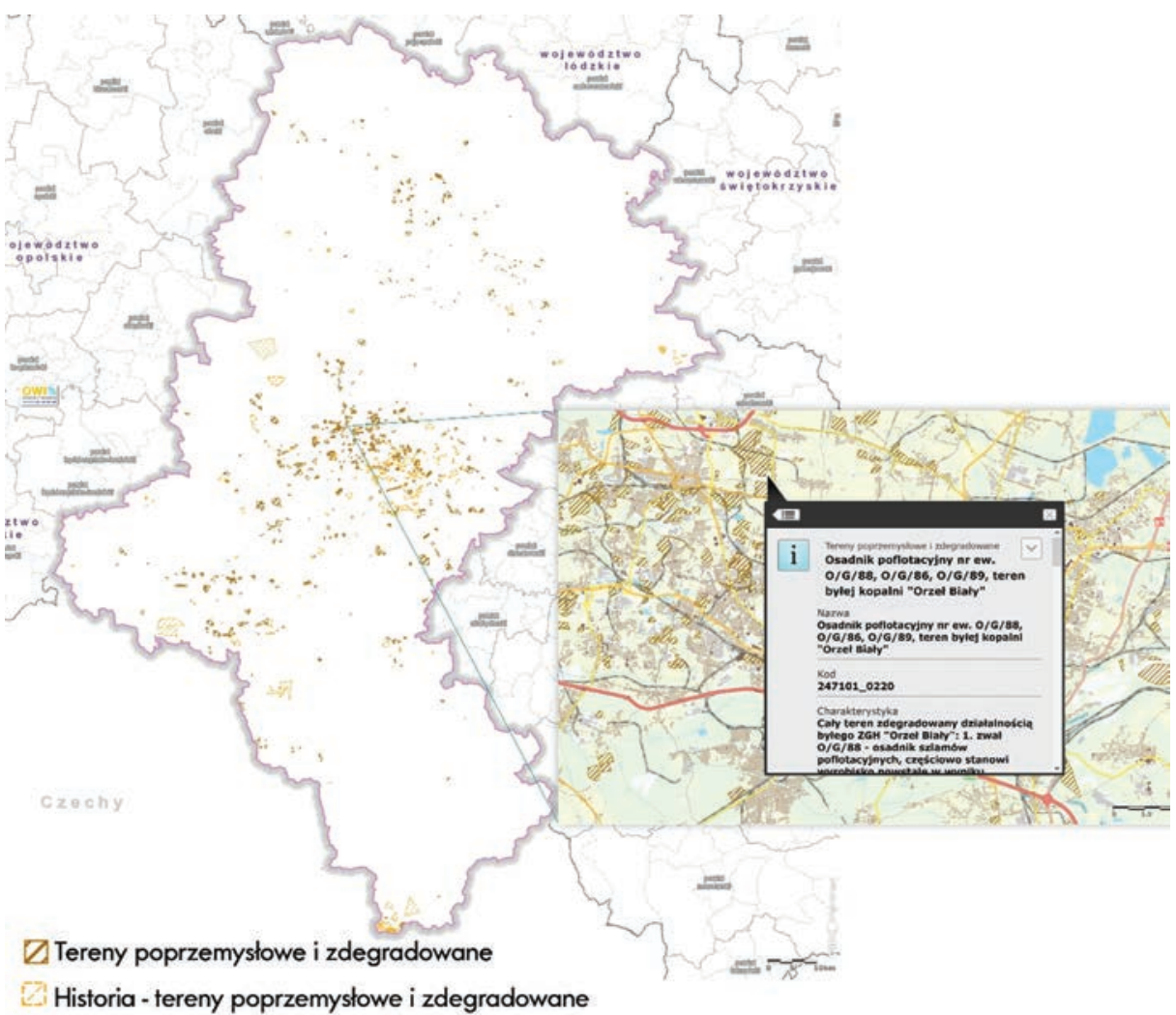

Ryc. 4. Tereny poprzemysłowe i zdegradowane w województwie śląskim - mapa systemu OPI -TPP, wraz z przykładową identyfikacją wybranego obszaru 
w Warszawie sporządził wykaz terenów o przekroczonym standardzie jakości gleby i ziemi oraz terenów zdegradowanych działalnością przemysłową. Zidentyfikowano 35 terenów poprzemysłowych o łącznej powierzchni 92 ha, z których 60 ha obejmowało tereny położone $\mathrm{w}$ miastach (24 obszary). Kolejne 32 ha to tereny zdegradowane w wyniku wydobywania kopalin.

Na terenie województwa małopolskiego, na zlecenie Urzędu Marszałkowskiego Województwa Małopolskiego, w 2003 r. wykonano szczegółową inwentaryzację terenów pokopalnianych $\mathrm{w}$ ramach projektu inwentaryzacji terenów skażonych w Małopolsce (ROPSIM). Z kolei $\mathbf{w}$ województwie podkarpackim opracowano bazę terenów zdegradowanych REWITAL w ramach projektu pt. "REWITAL - innowacje w rewitalizacji terenów zdegradowanych na Podkarpaciu". Jego głównym celem była promocja i identyfikacja innowacji $\mathrm{w}$ dziedzinie rewitalizacji terenów zdegradowanych $\mathrm{w}$ województwie. Baza ta identyfikuje budynki i obszary poprzemysłowe jedynie w 5 spośród 25 powiatów województwa, obejmuje zatem tylko 18 budynków i 3 obszary poprzemysłowe [Huculak 2009; Zagórska 2013].

Warto podkreślić, iż projekty rewitalizacyjne często inicjowane są oddolnie przez lokalną społeczność. Ze względu na brak ogólnodostępnej informacji dotyczącej lokalizacji terenów poprzemysłowych i ewentualnych zanieczyszczeń, zdarzają się przypadki, gdy deweloperzy lokalizują inwestycje o funkcjach mieszkaniowych lub handlowo-usługowych na terenach atrakcyjnych lokalizacyjnie, gdzie wcześniej funkcjonowały zakłady

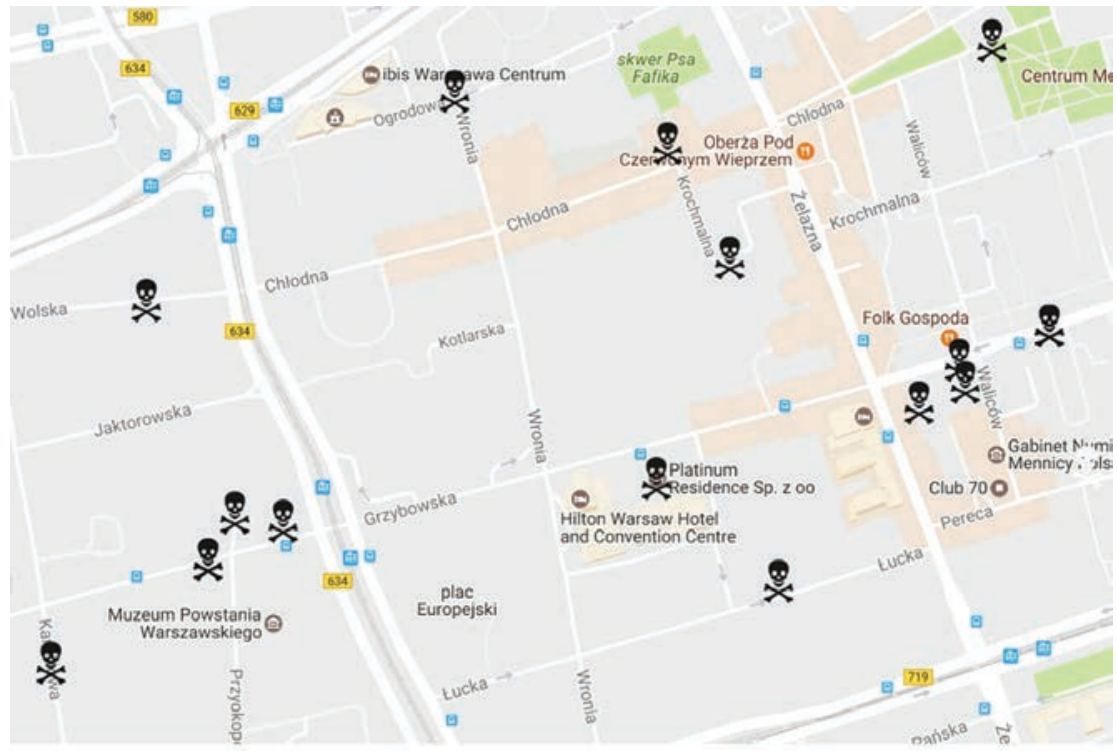

Miejsce potencjalnego historycznego zanieczyszczenia gruntu

Ryc. 5. Miejsca potencjalnych, historycznych skażeń gruntu na terenie dzielnicy Wola w Warszawie 
przemysłowe. Tereny te nie zawsze podlegają badaniom $\mathrm{w}$ zakresie stężenia substancji szkodliwych, a w konsekwencji nie są poddawane rekultywacji. Mieszkańcy w obawie o własne zdrowie, chcąc przeciwdziałać takim sytuacjom, na własną rękę tworzą mapy potencjalnych skażeń gruntu. Mapa taka powstała np. na terenie dzielnicy Wola w Warszawie (ryc. 5), po pojawieniu się problemów z kilkoma inwestycjami (m.in. przy ulicach Skierniewickiej i Obozowej 20). Mieszkańcy dzielnicy Wola opracowali mapę miejsc, w których w przeszłości znajdowały się zakłady przemysłowe. Pomimo braku profesjonalizmu w sposobie opracowania kartograficznego, a także poważnych braków metodycznych, opracowanie to należy uznać za cenny przykład aktywności społecznej w zakresie wiedzy ekologicznej oraz analizy zagrożeń dla zdrowia ludzi, mających znaczenie w procesie rewitalizacji [Turek 2017].

\section{Proces rewitalizacji i skala potrzeb na obszarze województwa mazowieckiego}

Województwo mazowieckie zajmuje powierzchnię $35558,47 \mathrm{~km}^{2}$, wydzielonych jest 37 powiatów i 5 miast na prawach powiatu. Powiaty dzielą się na 314 gmin, w tym 35 miejskich, 50 miejsko-wiejskich i 229 wiejskich. Obszar województwa zamieszkuje około 5,2 mln osób, z czego 33\% stanowią mieszkańcy Warszawy.

Województwo należy do najbardziej zróżnicowanych wewnętrznie województw w kraju - składa się z aglomeracji warszawskiej, pełniącej dominującą rolę społeczno-gospodarczą oraz transportowa, ale również obszarów charakteryzujących się wskaźnikami rozwoju ekonomicznego poniżej średniej krajowej. Województwo mazowieckie przyciąga najwięcej inwestycji zagranicznych $\mathrm{w}$ kraju i ma największy wkład $\mathrm{w}$ tworzenie polskiego PKB. Dominującą rolę odgrywa przemysł rolno-spożywczy i petrochemiczny, a także przemysł energetyczny, chemiczny i elektromaszynowy. Na Mazowszu zarejestrowanych jest około 650 tys. firm. Poza aglomeracją warszawską region ma głównie charakter rolniczy [Mazovia 2018].

Zagadnienie zagospodarowania przestrzennego obiektów i obszarów poprzemysłowych na obszarze województwa mazowieckiego powinno stanowić jedno z najważniejszych wyzwań planowania i rozwoju regionalnego.

Wynika to z faktu, że obszary poprzemysłowe cechują się zwykle znaczną powierzchnia, często strategiczną lokalizacją (położenie w centralnych częściach gminy), a także wysokim stopniem wyposażenia w infrastrukturę techniczną. Decyduje to o ich znaczącym potencjale i atrakcyjności dla przyszłego rozwoju przestrzennego gmin, a tym samym regionów. Odnowa i rewitalizacja obszarów poprzemysłowych oraz nadanie im nowych funkcji oczekiwane jest w kontekście zrównoważonego rozwoju regionów. Rewitalizacja jest złożonym i kosztownym procesem, rozwiązującym problemy o charakterze społecznym, gospodarczym, przyrodniczym, kulturowym, a przede wszystkim urbanistycznoprzestrzennym. Proces rewitalizacji obszarów zdegradowanych wymaga często przeprowadzenia zabiegów remediacji bądź rekultywacji z poszanowaniem uwarunkowań przyrodniczych, kulturowych i historycznych. 
W związku z powyższym, istotnym wyzwaniem staje się wykonanie szczegółowej charakterystyki, analizy i oceny obszarów poprzemysłowych na obszarze województwa mazowieckiego, które będą stanowić podstawę do kreowania przyszłego zagospodarowania obszarów poprzemysłowych, nadając im nowe funkcje, adekwatne do oczekiwań społeczności lokalnej i strategii rozwoju regionu.

Potrzeba wykonania szczegółowej charakterystyki obszarów poprzemysłowych oraz ich ocena wynika również z obowiązku prawa obowiązującego w Polsce, które w ostatnich latach uległo istotnym zmianom ze względu na konieczność dostosowania przepisów do wymagań unijnych. Ważnym krokiem w tym zakresie było Rozporządzenie Ministra Środowiska z dnia 1 września 2016 r. w sprawie rejestru historycznych zanieczyszczeń powierzchni ziemi (Dz.U. z 2016 r., poz. 1397). Rozporządzenie to nakazuje m.in. opracowanie mapy gruntów zanieczyszczonych historycznie. Dotychczasowe dostępne dane odnoszące się do powierzchni terenów zdegradowanych i poprzemysłowych w Polsce charakteryzują się brakiem szczegółowości istotnych w podejmowaniu decyzji o przeznaczeniu tych obszarów do pełnienia nowych funkcji. Generuje to szereg zagrożeń w szczególności dla społeczności lokalnych. Wskazuje to na potrzebę zapewnienia zintegrowanych i transparentnych informacji o tych obszarach. Stworzenie rozwiązań systemowo wspierających zagospodarowanie obszarów zdegradowanych zdecydowanie przyczyni się do racjonalnego ich wykorzystania i będzie mieć istotne znaczenie w kontekście polityki przestrzennej regionu [Turek 2017].

\section{Podsumowanie}

Rewitalizacja obszarów poprzemysłowych, poprzedzona często koniecznością ich rekultywacji, jest procesem długotrwałym oraz wymaga interdyscyplinarnego i zintegrowanego podejścia. Proces ten powinien być ukierunkowany na aktywizację i integrację społeczną mieszkańców zdegradowanych obszarów, zmierzającą do stopniowego podnoszenia jakości ich życia. Strategiczne programowanie rozwoju lokalnego i regionalnego, a w szczególności procesu rewitalizacji, powinno być oparte na wynikach analiz dotyczących koncentracji zjawisk kryzysowych na obszarze województwa mazowieckiego. Takie ujęcie tematu umożliwi zaplanowanie i koordynację działań odpowiadających na problemy zidentyfikowane na danym obszarze. 


\section{Literatura}

Billert A., 2010, Polityka rozwoju i rewitalizacji miast w Polsce na tle standardów unijnych w zakresie planowania, Urbanistyka INFO.

http://www.urbanistyka.info/content/polityka-rozwoju-i-rewitalizacja-miast-w-polsce-natle-standard\%C3\%B3w-unijnych-w-zakresie-planow[dostęp: 10.01.2017].

Bondaruk J., Zawartka P., 2011, Ogólnodostepna Platforma Informacji „Tereny Poprzemysłowe $i$ Zdegradowane" (OPI-TPP) - nowoczesne narzędzie systemowego zarzadzania informacją o terenach poprzemysłowych w województwie śląskim, Prace Naukowe GIG, Górnictwo i Środowisko, 4 s. 31-49.

Chmielewska M., 2012, Kompleksowa i wielokierunkowa rewitalizacja zdegradowanej przestrzeni miejskiej w dzielnicy Hörde miasta Dortmund (Zagłębie Ruhry, Niemcy), [w:] Ksztattowanie środowiska geograficznego i ochrona przyrody na obszarach uprzemysłowionych $i$ zurbanizowanych, 44, Uniwersytet Śląski, Wydział Biologii i Ochrony Środowiska \& Wydział Nauk o Ziemi, Katowice-Sosnowiec, s. 5-15.

Chmielewski J.M., 2007, Lokalny Program Rewitalizacji - problemy wdrażania, [w:] P. Lorens (red.), Rewitalizacja miast w Polsce. Pierwsze doświadczenia, Urbanista, Warszawa, s. 310-318.

Cymerman R., 1988, Rekultywacja gruntów zdewastowanych, Skrypty Akademii RolniczoTechnicznej w Olsztynie, Wydawnictwo ART, Olsztyn.

Cymerman R., Marcinkowska I., 2010, Techniczne i przestrzenne aspekty rekultywacji gruntów, Wydawnictwo Uniwersytetu Warmińsko-Mazurskiego w Olsztynie, Olsztyn.

Domański B., 2009, Rewitalizacja terenów poprzemystowych - specyfika wyzwań i instrumentów, [w:] W. Jarczewski (red.), Przestrzenne aspekty rewitalizacji - śródmieścia, blokowiska, tereny poprzemysłowe, pokolejowe i powojskowe, Instytut Rozwoju Miast, Kraków, s. 125-137.

Gasidło K., 1998, Problemy przekształceń terenów poprzemysłowych, Wydawnictwo Politechniki Śląskiej, Gliwice.

Gasidło K., 2010, Kierunki przeksztatceń przestrzeni przemystu, Wydawnictwo Politechniki Śląskiej, Gliwice.

Główny Urząd Statystyczny, 2016, Grunty zdegradowane $i$ zdewastowane, wymagajace rekultywacji wg województw w 2015 r., Warszawa.

Główny Urząd Statystyczny, 2017, Ochrona Środowiska 2017, Warszawa. 
Huculak M., 2009, Rewitalizacja terenów poprzemysłowych. Polskie doświadczenia i perspektywy, [w:] W. Jarczewski (red.), Przestrzenne aspekty rewitalizacji - śródmieścia, blokowiska, tereny poprzemystowe, pokolejowe i powojskowe, Instytut Rozwoju Miast, Kraków, s. 139-197.

Hunger B., Weidemüller D., Westermann S., 2005, Przekształcanie Krajobrazów: zalecenia na przykładzie trzech europejskich krajobrazów poprzemysłowych. Włosko-polsko-niemiecki projekt REKULA - „Przekształcenia krajobrazów kulturowych", Internationale Bauausstellung (IBA) Fürst-Pückler-Land, Grossräschen.

IETU/GIG, 2008, Wojewódzki program przekształceń terenów poprzemysłowych $i$ zdegradowanych wraz z koncepcja rozbudowy narzędzi informatycznych oraz prognoza jego oddziatywania na środowisko. Regionalny system wspomagania zarzadzaniem terenami poprzemysłowymi w gminach, Instytut Ekologii Terenów Uprzemysłowionych, Główny Instytut Górnictwa, Katowice.

Jarczewski W., 2010, Skala degradacji miast w Polsce, [w:] Z. Ziobrowski, W. Jarczewski (red), Rewitalizacja miast polskich - diagnoza, Instytut Rozwoju Miast, Kraków, s. 57-64.

Kołacz P., Wielgus P., 2015, Przepis na rewitalizację. Poradnik Samorzadowca, Fundacja dla Uniwersytetu Kazimierza Wielkiego, Bydgoszcz.

Kopeć M., 2010, Rewitalizacja miejskich obszarów zdegradowanych, Wydawnictwo C.H. Beck, Warszawa.

Maciejewska A., 2000, Rekultywacja i ochrona środowiska w górnictwie odkrywkowym, Oficyna Wydawnicza Politechniki Warszawskiej, Warszawa.

Maciejewska A., Turek A., 2014, Rewitalizacja obszarów poprzemysłowych ze szczególnym uwzględnieniem uwarunkowań środowiska przyrodniczego - wybrane studia przypadków, Problemy Rozwoju Miast, 11, 2, s. 81-94.

Mapa zagrożeń gruntu. 68 punktów na Woli, TVN Warszawa, http://tvnwarszawa.tvn24.pl/ informacje,news,mapa-zagrozen-gruntu-68-punktow-na-woli,196808.html, [dostęp: 18.10.2016].

Mazovia, 2018, www.mazovia.pl

Mersey Valley Countryside Warden Service, http://www.merseyvalley.org.uk/site/, [dostęp: 15.02.2014].

Ministerstwo Infrastruktury i Budownictwa, Departament Polityki Przestrzennej, 2016, Ustawa o rewitalizacji. Praktyczny komentarz.

Ministerstwo Rozwoju, 2015, Sejm uchwalit ustawę o rewitalizacji, https://www.mr.gov.pl/ strony/aktualnosci/sejm-uchwalil-ustawe-o-rewitalizacji/, [dostęp: 08.08.2015]. 
Minister Rozwoju, 2016, Wytyczne w zakresie rewitalizacji w programach operacyjnych na lata 2014-2020, (MR/H 2014-2020/20(2)08/2016), Warszawa.

Ministerstwo Środowiska, 2004, Program rządowy dla terenów poprzemysłowych przyjęty przez Radę Ministrów w dniu 27 kwietnia 2004 r., Warszawa.

Muzioł-Węcławowicz A., 2009, Rewitalizacja dzielnic śródmiejskich, [w:] W. Jarczewski (red.), Przestrzenne aspekty rewitalizacji - śródmieścia, blokowiska, tereny poprzemystowe, pokolejowe i powojskowe, Instytut Rozwoju Miast, Kraków, s. 25-88.

OPI-TPP Ogólnodostępna Platforma Informacji Tereny Poprzemysłowe i Zdegradowane, http://opitpp.orsip.pl/imap [dostęp: 20.01.2016]

Siuta J., Kucharska A., Sienkiewicz R., 1996, [mapa w skali 1: 750 000] Polska - Wieloczynnikowa Degradacja Środowiska, Państwowa Inspekcja Ochrony Środowiska - Instytut Ochrony Środowiska, Warszawa.

Skalny A., Białecka B., 2016, Determinanty modelu wyceny terenów poprzemysłowych, Zeszyty Naukowe Politechniki Śląskiej, Seria: Organizacja i Zarządzanie, 87, s. 313-325.

Trafford Metropolitan Borough, 1993, Trafford Unitary Development Plan - written statement, Trafford.

Tödtling-Schönhofer H., Davies S., 2013, Regionale Strategien für Industriegebiete. Themenpapier,

http://www.europarl.europa.eu/RegData/etudes/note/join/2013/495848/IPOL-REGI_ NT\%282013\%29495848_DE.pdf

Turek A., 2017, Analiza możliwości zagospodarowania obszarów poprzemysłowych na terenach miejskich ze szczególnym uwzględnieniem uwarunkowań przyrodniczych, Rozprawa doktorska, Wydział Geodezji i Kartografii Politechniki Warszawskiej, Warszawa.

Urbańczyk Ł., 2009, Zabytki poprzemysłowe szansa rozwoju miast, [w:] B. Szmygina (red.), Adaptacja obiektów zaby tkowych do współczesnych funkcji użytkowych, Wydawnictwo Politechniki Lubelskiej, Warszawa-Lublin, s. 189-201.

Ustawa z dnia 3 lutego 1995 r. o ochronie gruntów rolnych i leśnych (Dz.U. z 2015 r., poz. 909 z późn. zm.).

Ustawa z dnia 27 marca 2003 r. o planowaniu i zagospodarowaniu przestrzennym (Dz.U. z 2016 r., poz. 778 z późn. zm.).

Ustawa z dnia 9 października 2015 r. o rewitalizacji (Dz.U. z 2015 r., poz. 1777 z późn. zm.). 
Uzasadnienie rządowego projektu ustawy o rewitalizacji, 2015 http://www.sejm.gov.pl/ Sejm7.nsf/druk.xsp?nr=3594

Zagórska E., 2013, Wojewódzkie bazy danych o terenach poprzemysłowych $i$ zdegradowanych jako przykład podejmowanych działań w dziedzinie rewitalizacji terenów poprzemysłowych $i$ zdegradowanych, Studia Ekonomiczne, 155, Uniwersytet Ekonomiczny w Katowicach, Katowice, s. 108-121. 


\title{
The process of urban renewal and its importance in the implementation of spatial policy in the Mazowieckie Voivodeship
}

\begin{abstract}
The constant growth of cities requires the adoption of comprehensive solutions concerning the organization of their structure. The revitalization of degraded post-industrial areas and consequent reorientation of cities' development to their interior can play a key role in the implementation of the principle of sustainable development in the spatial planning process.

The objective of the paper is to indicate the demand for and importance of urban renewal in local and regional development. The paper outlines the history of the revitalization process in Poland, discusses the characteristics and scale of the degradation of postindustrial areas, with particular emphasis on the Mazowieckie Voivodeship. Also indicated are examples of foreign best practice in the field of revitalization of post-industrial areas.
\end{abstract}

Key words: urban renewal, post-industrial areas, brownfields, degraded areas, Mazovia

Prof. dr hab. Alina Maciejewska, prof. zw. - Dziekan Wydziału Geodezji i Kartografii Politechniki Warszawskiej na kadencję 20122016 i 2016-2020; specjalność naukowa: inżynieria środowiska glebowego, gleboznawstwo, rekultywacja i zagospodarowanie terenów zdegradowanych, rewitalizacja terenów powojskowych i poprzemysłowych; Autorka lub współautorka ponad 200 prac, 6 monografii, 3 ksiq̨żek oraz 12 opracowań wdrożeniowych; kontakt: Wydział Geodezji i Kartografii, Politechnika Warszawska, Pl. Politechniki 1, pok.301, tel: 22234 - 7223, e-mail: alina.maciejewska@pw.edu.pl

Professor Alina Maciejewska - Dean of the Faculty of Geodesy and Cartography of the Warsaw University of Technology for the terms 2012-2016 and 2016-2020; research interests: soil environment engineering, soil science, reclamation and management of degraded areas, revitalization of post-military and post-industrial areas; author or co-author of over 200 works, 6 monographs, 3 books and 12 implementation studies; contact: Faculty of Geodesy and Cartography, Warsaw University of Technology, pl. Politechniki 1, room 301, tel: +4822 234 7223, e-mail: alina.maciejewska@pw.edu.pl

Dr inż. Agnieszka Turek - adiunkt na Wydziale Geodezji i Kartografii Politechniki Warszawskiej, Katedra Gospodarki Przestrzennej i Nauk o Środowisku Przyrodniczym; specjalność naukowa: rekultywacja i rewitalizacja obszarów poprzemysłowych na terenach miejskich, zastosowaniu narzędzi GIS w badaniu obszarów zdegradowanych, wykorzystanie technologii geoinformacyjnych w procesie geopartycypacji społecznej, spatial data mining, zagadnienia zwiqzane z rozwojem inteligentnych miast; kontakt: Wydział Geodezji i Kartografii, Politechnika Warszawska, PI. Politechniki 1, pok. 245, tel: 22 234-5062, e-mail: agnieszka.turek@pw.edu.pl

Agnieszka Turek, PhD eng - Assistant Professor at the Faculty of Geodesy and Cartography of the Warsaw University of Technology, Department of Spatial Management and Environmental Sciences; research interests: reclamation and revitalization of postindustrial urban areas, application of GIS tools in the study of degraded areas, the use of geoinformation technologies in the process of social geoparticipation, spatial data mining, issues related to the development of smart cities; contact: Faculty of Geodesy and Cartography, Warsaw University of Technology, pl. Politechniki 1, room 245, tel: +48 22234 5062, e-mail: agnieszka.turek@pw.edu.pl 